\title{
Front Matter: Volume 11561
}

, "Front Matter: Volume 11561," Proc. SPIE 11561, First iiScience International Conference 2020, 1156101 (27 August 2020); doi: 10.1117/12.2583293

SPIE Event: First iiScience International Conference: Light Generation, Sensing \& Energy Sources, 2020, Multan, Pakistan 


\title{
PROCEEDINGS OF SPIE
}

\section{First iiScience International Conference 2020}

\author{
M. Yasin Akhtar Raja \\ Imran Shakir \\ Syed A. Haider \\ Editors
}

2-4 March 2020

Multan, Pakistan

Organized by

University of North Carolina, Charlotte (United States)

The Women University Multan (Pakistan)

Sponsored by

PHEC_-Punjab Higher Education Commission (Pakistan)

Published by

SPIE

Volume 11561 
The papers in this volume were part of the technical conference cited on the cover and title page. Papers were selected and subject to review by the editors and conference program committee. Some conference presentations may not be available for publication. Additional papers and presentation recordings may be available online in the SPIE Digital Library at SPIEDigitalLibrary.org.

The papers reflect the work and thoughts of the authors and are published herein as submitted. The publisher is not responsible for the validity of the information or for any outcomes resulting from reliance thereon.

Please use the following format to cite material from these proceedings:

Author(s), "Title of Paper," in First iiScience International Conference 2020, edited by M. Yasin Akhtar Raja, Imran Shakir, Syed A. Haider, Proceedings of SPIE Vol. 11561 (SPIE, Bellingham, WA, 2020)

Seven-digit Article CID Number.

ISSN: 0277-786X

ISSN: 1996-756X (electronic)

ISBN: 9781510639430

ISBN: 9781510639447 (electronic)

Published by

SPIE

P.O. Box 10, Bellingham, Washington 98227-0010 USA

Telephone +1 3606763290 (Pacific Time) · Fax +1 3606471445

SPIE.org

Copyright (c) 2020, Society of Photo-Optical Instrumentation Engineers.

Copying of material in this book for internal or personal use, or for the internal or personal use of specific clients, beyond the fair use provisions granted by the U.S. Copyright Law is authorized by SPIE subject to payment of copying fees. The Transactional Reporting Service base fee for this volume is $\$ 21.00$ per article (or portion thereof), which should be paid directly to the Copyright Clearance Center (CCC), 222 Rosewood Drive, Danvers, MA 01923. Payment may also be made electronically through CCC Online at copyright.com. Other copying for republication, resale, advertising or promotion, or any form of systematic or multiple reproduction of any material in this book is prohibited except with permission in writing from the publisher. The CCC fee code is $0277-$ $786 \mathrm{X} / 20 / \$ 21.00$.

Printed in the United States of America by Curran Associates, Inc., under license from SPIE.

Publication of record for individual papers is online in the SPIE Digital Library.

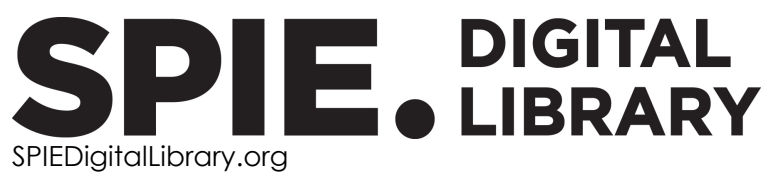

Paper Numbering: Proceedings of SPIE follow an e-First publication model. A unique citation identifier (CID) number is assigned to each article at the time of publication. Utilization of CIDs allows articles to be fully citable as soon as they are published online, and connects the same identifier to all online and print versions of the publication. SPIE uses a seven-digit CID article numbering system structured as follows:

- The first five digits correspond to the SPIE volume number.

- The last two digits indicate publication order within the volume using a Base 36 numbering system employing both numerals and letters. These two-number sets start with 00, 01, 02, 03, 04, 05, 06, 07, 08, 09, OA, OB ... 0Z, followed by 10-1Z, 20-2Z, etc. The CID Number appears on each page of the manuscript. 


\section{Contents}

FIRST IISCIENCE INTERNATIONAL CONFERENCE 2020

1156102 Analytical analysis of piezoelectric field on the optoelectronic characteristics of green GaNbased light-emitting diodes [11561-2]

1156103 Structural and morphological analysis for cerium $\left(\mathrm{Ce}^{+3}\right)$ doped intercalated 2D MXene [11561-3]

1156104 Design and development of smart greenhouse for arid climate [11561-4]

1156105 Optoelectronic properties of the double perovskites $\mathrm{Ba}_{2} \mathrm{MM}^{\prime} \mathrm{O}_{6}\left(\mathrm{M}=\mathrm{Sc}, \mathrm{Y}, \mathrm{La} ; \mathbf{M}^{\prime}=\mathbf{N b}, \mathrm{Ta}\right)$ by modified Becke-Johnson potential [11561-6]

1156106 Graphite-metal rechargeable battery [11561-7]

1156107 Comparison thermal properties of $\mathrm{R} 134 \mathrm{a} / \mathrm{TiO}_{2}$ and its alternative $\mathrm{R} 513 \mathrm{a} / \mathrm{TiO}_{2}$ [1 1561-9]

1156108 The accomplishment of the phenomenon of perfect optical cloaking using a multi-lens system [11561-10]

1156109 Electronic and magnetic properties of Tm doped ZnO: a first principle study [11561-13]

$115610 \mathrm{~A}$ A role of $\mathrm{B}$-site cation on structural and transport properties of $\mathrm{La}_{2} \mathrm{BMnO}_{6}(\mathrm{~B}=\mathrm{Cr}, \mathrm{Fe}, \mathrm{Co}, \mathrm{Ni}, \mathrm{Cu}$, Zn) double perovskites [11561-14]

$11561 \mathrm{OB} \quad$ Structural and electrical properties of $\mathrm{La}^{3+}$ doped $\mathrm{BiFeO}_{3}$ multiferroics [1 1561-15] 
Proc. of SPIE Vol. 11561 1156101-4

\section{Downloaded From: https://www.spiedigitallibrary.org/conference-proceedings-of-spie on 26 Apr 2023
Terms of Use: https://www.spiedigitallibrary.org/terms-of-use}

